GRASAS Y ACEITES 69 (4)

October-December 2018, e276

ISSN-L: 0017-3495

https://doi.org/10.3989/gya.0109181

\title{
Influences of genotype and location interactions on oil, fatty acids and agronomical properties of groundnuts
}

\author{
E. Yol and B. Uzun ${ }^{\bowtie}$ \\ Department of Field Crops, Faculty of Agriculture, Akdeniz University, Antalya, Turkey \\ ${ }^{凶}$ Corresponding author: bulentuzun@akdeniz.edu.tr
}

Submitted: 19 January 2018; Accepted: 01 June 2018

SUMMARY: An enhanced adaptation to specific environmental conditions could provide higher seed quality and quantity from groundnuts. In this investigation, nine groundnut genotypes and two controls were evaluated for morphological and oil traits in two different Mediterranean locations. The traits of shelling percentage and pod yield indicated significant differences among the genotypes. The highest pod yield was observed for ACG 154 from the subsp. hypogaea var. hypogaea and ACG 107 from the subsp. fastigiata var. vulgaris in the locations of Adana and Antalya, respectively. The genotype ACG 154 also had about $60 \mathrm{~g}$ of 100-seed weight, which is desirable for commercial production as a Runner commercial type. Significant differences were recorded for oil yield, palmitic, oleic and linoleic acids in both locations among the genotypes studied. The groundnut genotypes were further evaluated with allele-specific PCR markers for possible SNP mutations in the ahFAD2A and ahFAD2B genes for high-oleic mutants. ACG 14, ACG 154 and ACG 156 had the mutant ahFAD2A allele, while no $a h F A D 2 B$ allele mutation was found. The statistical model GGE bi-plot was used to identify the ideal and representative location for each genotype according to pod yield performance. The genotypes ACG 107 and ACG 116 presented the highest oil yield and were relatively stable across locations. Therefore, they should be evaluated as candidates for cultivar releases in the two studied climatic areas. In addition, the selected desirable genotypes in this study can be used as parents in hybridization programs to develop populations for future releases.

KEYWORDS: FAD2 genes; GxE interaction; Genetic diversity; Peanut

RESUMEN: Influencia de las interacciones del genotipo y ubicación sobre el aceite, los ácidos grasos y las propiedades agronómicas del maní. El maní, teniendo una mejor adaptación a las condiciones ambientales específicas, podría proporcionar una mayor calidad y cantidad de semillas. En esta investigación, nueve genotipos de cacahuete y dos controles procedentes de dos lugares diferentes del Mediterráneo se evaluaron en relación a las características morfológicas y al aceite. Los rasgos de porcentajes de descascarillado y la producción de la vaina indicaron diferencias significativas entre genotipos así como del rendimiento de la vaina. El rendimiento de vaina más alto se observó en ACG 154 a partir de la subsp. hypogaea var. hypogaea y ACG 107 de subsp. fastigiata var. vulgaris en las ubicaciones de Adana y Antalya, respectivamente. El genotipo ACG 154 también tenía aproximadamente 60 por ciento en peso de semilla que es un valor deseable para la producción comercial un mercado tipo. Se registraron diferencias significativas para el rendimiento de aceite, para los ácidos palmítico, oleico y linoleico en ambos lugares entre los genotipos. Se evaluaron además, los marcadores de PCR específicos de alelo para posibles mutaciones de SNP en genes $a h$ FAD2A y $a h$ FAD2B para mutantes de alto contenido de ácido oleico. ACG 14, ACG 154 y ACG 156 tenían el alelo ahFAD2A mutante mientras que no había mutación del alelo ahFAD2B. El modelo estadístico GGE biplot se utilizó para identificar la ubicación ideal y representativa para cada genotipo en el rendimiento de la cápsula. Los genotipos, ACG 107 y ACG 116, tuvieron mayor rendimiento de aceite y eran relativamente estables en todas las ubicaciones, por lo que deberían evaluarse como candidatos para extender los cultivares en las dos áreas climáticas estudiadas. Además, los genotipos deseables seleccionados en este estudio se pueden utilizar como padres en programas de hibridación para desarrollar poblaciones para futuras liberaciones.

PALABRAS CLAVE: Diversidad genética; Genes FAD2; Interacción GxE; Maní

ORCID ID: Yol E https://orcid.org/0000-0002-3152-6078, Uzun B https://orcid.org/0000-0001-6228-9629

Citation/Cómo citar este artículo: Yol E, Uzun B. 2018. Influences of genotype and location interactions on oil, fatty acids and agronomical properties of groundnut. Grasas Aceites 69 (4), e276. https://doi.org/10.3989/gya.0109181

Copyright: ( 2018 CSIC. This is an open-access article distributed under the terms of the Creative Commons Attribution 4.0 International (CC BY 4.0) License. 


\section{INTRODUCTION}

The groundnut, also referred to as peanut (Arachis hypogaea L.), is an important oilseed crop which is generally cultivated in tropical, subtropical and warm, temperate areas (Hammons, 1994). Groundnut seeds are a major source of protein and oil for human nutrition, containing about $28 \%$ protein, $50 \%$ oil and $18 \%$ carbohydrates. Groundnut oil includes eight different fatty acids, although oleic and linoleic acids account for about $80 \%$ of the total fatty acid composition (Ahmed and Young, 1982). High oleic acid provides an extended shelf life for groundnut-derived products in food applications and has health benefits such as lowering blood pressure and the risk of heart diseases (Terés et al., 2008). The groundnut haulm is also a valuable forage for cattle (Cook and Crosthwaite, 1994).

Breeding cultivars with high yield is one of the major objectives for groundnut-breeding programs (Chen et al., 2016). High oil content and oleic acid are also important selection criteria because of commercial demands. Most groundnut improvement programs rely on the use of established cultivars and elite breeding lines in specific environments and/or locations (Halward and Wyne, 1991) because groundnut is highly sensitive to growing conditions. Furthermore, yield and quality traits are affected by the environment (Badigannavar et al., 2002). There are few examples in the literature which describe the importance of selection according to the specific environment/location for groundnut yield and quality traits. The effects of environment on oil content and fatty acid composition were studied in 12 different locations by Dwivedi et al., (1993). The Asian groundnut core collection was evaluated in two different seasons and the environmental effect was observed for important yield traits (Swamy et al., 2003). This collection was also studied by Upadhyaya et al., (2005) for twelve traits in three locations and six environments in order to choose desirable parents for the target regions of the crop. Phan-Thien et al., (2014) displayed the genotype-by-environment effect on the groundnut antioxidant capacity of raw kernels in Australia. Molecular marker-assisted selection was also conducted in groundnut breeding programs to select high-oleic genotypes. The earlier studies indicated that point mutations in fatty acid desaturase (ahFAD) alleles in the A-genome (Jung et al., 2000) and B-genome (Lopez et al., 2000) caused elevated high oleic acid. Molecular markers developed by different researchers (Chu et al., 2007; 2009; Chen et al., 2010) have provided effective characterization of high-oleic mutants.

Although groundnut cultivation is more common in tropical climates, Mediterranean environments also present suitable conditions for both vegetative and reproductive growth of groundnuts. These areas allow second-crop production after wheat harvest to provide for sustainable farming. However, there is a limited effort to develop cultivars for this kind of climatic area (Caliskan et al., 2008). The use of economically important agronomic traits is an appropriate step for the selection of useful germplasm in these areas. For this purpose, a wide groundnut genetic resource was previously evaluated by Yol et al., (2018) for quantitative and qualitative traits under the Mediterranean environmental conditions over three consecutive years. In the present investigation, nine advanced breeding lines selected from this collection were subjected to further investigation with respect to economically important agronomic and oil traits in two different locations to develop superior groundnut cultivars adapted to the Mediterranean climate.

\section{MATERIAL AND METHODS}

\subsection{Plant material, experimental areas and climate conditions}

The plant material used in this study was selected from a diverse groundnut collection consisting of 256 genotypes. The quantitative and qualitative properties of the collection were detailed in the previous investigations of Yol et al., (2015, 2016, 2017, 2018). Nine groundnut genotypes were selected from these 256 genotypes after three years of field studies. This genetic resource consists of seven genotypes belonging to the subsp. fastigiata var. vulgaris, one genotype from the subsp. fastigiata var. fastigiata and one to the subsp. hypogaea var. hypogaea. Two registered cultivars NC-7 (subsp. hypogaea) and Florispan (subsp. fastigiata) were used as controls. The field studies were performed at the West Mediterranean Agricultural Research Institute at Antalya $\left(36^{\circ} 52^{\prime} \mathrm{N}, 30^{\circ} 50^{\prime} \mathrm{E}\right)$ and the farmed field at Adana $\left(36^{\circ} 51^{\prime} \mathrm{N}, 35^{\circ} 32^{\prime} \mathrm{E}\right)$, Turkey during the 2014 and 2015 growing seasons. Antalya and Adana where the experimental fields are located have coastline formed by the Mediterranean Sea (Figure 1)

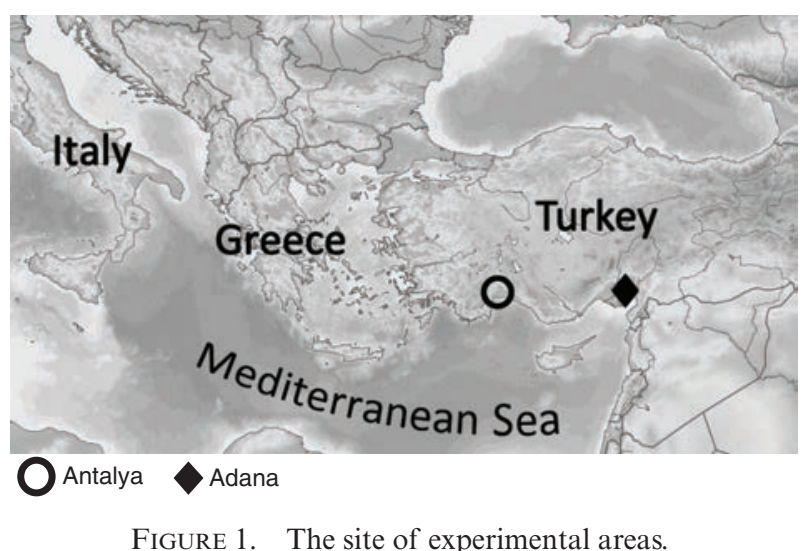

FIGURE 1. The site of experimental areas. 
and have typical Mediterranean climates. The field experiments were conducted with a randomized complete-blocks design with three replicates. The soil structure of the experimental fields of Adana and Antalya had clay silt loam with a $\mathrm{pH}$ of 7.6 and 7.8 , respectively. Each genotype was grown in two rows of $5 \mathrm{~m}$ length with a spacing of $70 \mathrm{~cm}$ between rows and $20 \mathrm{~cm}$ between plants within rows. Plant residues were removed before sowing, and furrow irrigation was used. Fertilizer was applied before seeding at the rate of $30 \mathrm{~kg} / \mathrm{ha}$ using an N-P2O5 formula at 18-46-0. The genotypes were sown at the end of May in both years in the two locations.

\subsection{Oil extraction}

The seeds were cleaned and dried in an oven at 105 ${ }^{\circ} \mathrm{C}$ for $48 \mathrm{~h}$ before the extraction procedure. Twelve grams of seeds of each genotype were crushed using a homogenizator (Heidolph Silent Crusher M, Germany) and transferred into a thimble topped with cotton. This was followed by oil extraction using a conventional Soxhlet method with petroleum ether $\left(40-60^{\circ} \mathrm{C}\right)$ for $4 \mathrm{~h}$ using a Soxhlet apparatus (Gerhardt, model 173200, EV, Germany). A rotary flash evaporator (Heidolph, model Laborota 4000 , Germany) was used to remove the solvent. The percent oil content of the seeds and oil yield was determined using the following formulas:

Oil content $(\%)=\frac{\text { Weight of oil extracted }(\mathrm{g})}{\text { Weight of the seed sample }(\mathrm{g})} \times 100$

Oil yield $\left(\mathrm{kg} \cdot \mathrm{ha}^{-1}\right)=$ Seed yield $\left(\mathrm{kg} \cdot \mathrm{ha}^{-1}\right) \times$ Oil content $(\%)$

\subsection{Methylation and gas chromatography}

An official analysis method (Garcés and Mancha, 1993) was used for the conversion of methyl esters. Here, $2 \mathrm{~mL}$ of heptan were added to $0.1 \mathrm{~g}$ oil and mixed. After adding $0.2 \mathrm{~mL}$ of $2 \mathrm{~N}$ potassium hydroxide $(\mathrm{KOH})$ prepared in methanol, the mixture was shaken vigorously for at least 30 seconds. Then, the mixture was allowed to sit for clarification of the upper phase. The obtained methyl esters were used for the fatty acid analysis in gas chromatography (GC). The fatty acid composition of the samples was analyzed by a gas chromatography (Agilent 5975C) coupled to a flame ionization detector and mass spectrometer (Agilent 5975C) using a capillary column (HP Innowax Capillary; $60.0 \mathrm{~m} \times 0.25 \mathrm{~mm} \times 0.25$ $\mu \mathrm{m})$. The GC-MS/FID analysis was performed at a split mode of 50:1. The injection volume and temperature were adjusted to $1 \mu \mathrm{L}$ and $250{ }^{\circ} \mathrm{C}$, respectively. Helium $(99.9 \%)$ was the carrier gas at a constant stream ratio of $0.8 \mathrm{~mL} / \mathrm{min}$. The oven temperature was standardized as follows: $150{ }^{\circ} \mathrm{C}$ for 10 minutes, increasing to $250{ }^{\circ} \mathrm{C}$ in $10{ }^{\circ} \mathrm{C} / \mathrm{min}$ increments, and then held at $250{ }^{\circ} \mathrm{C}$ for 5 minutes. The MS spectra were monitored between 35-450 amu and the ionization mode used had electronic impact at $70 \mathrm{eV}$. The percentage of the components was identified from the GC-FID peak areas, and WILEY, NIST and FLAVOR libraries identified the components at MS.

\subsection{Detection of functional SNPs in ahFAD2A and $a h F A D 2 B$ genes using allele-specific PCR markers}

Leaf samples from advanced breeding lines were collected and stored at $-80^{\circ} \mathrm{C}$ for DNA extraction. The high oleic breeding line, HOG (containing > $80 \%$ oleic acid) and normal oleic cultivar, NC-7 (55-60\% oleic acid) were also evaluated in the molecular analysis as controls. In total, 11 genotypes were studied for DNA isolation with use in the CTAB method (Doyle and Doyle, 1990). The quality and quantity of the DNA extracts were checked by agarose gel electrophoresis with a DNA standard. The DNA extracts were suspended in milli-Q PCR water and stored at $-20^{\circ} \mathrm{C}$.

Chen et al., (2010) designed markers to identify functional mutations in ahFAD2A and ahFAD2B genes which are located on linkage groups $\mathrm{a} 09$ and b09 in A-genome and B-genome, respectively. The PCR primers, F435-F(ATCCAAGGCTGCATTCTCAC) and F435SUB-R (TGGGACAAACACTTCGTT) produce a PCR product of 203-bp including the $\mathrm{G}: \mathrm{C} \rightarrow \mathrm{A}: \mathrm{T}$ substitution from the $\mathrm{A}$ genome. The forward primer, F435-F and insertion allele-specific reverse primer F435INS-R (AACACTTCGTCGCGGTCT) were used to amplify a PCR product of 195-bp containing an A:T insertion from the B genome. The PCR analyses were conducted for two different SNP detections and the templates for the PCR reaction were set up for $20 \mu \mathrm{L}$ as follows: $2 \mu \mathrm{L}$ of $10 \mathrm{x}$ PCR buffer, $0.4 \mathrm{mM}$ of dNTPs mix, $2.5 \mathrm{mM}$ of $\mathrm{MgCl}_{2}, 0.5 \mu \mathrm{M}$ each primer, 1 unit of Taq DNA polymerase (Fermentas Life Sciences, Burlington, Canada), $1 \mu \mathrm{L}$ genomic DNA template and milli-Q water to a final volume of $20 \mu \mathrm{L}$. The PCR conditions consisted of $94{ }^{\circ} \mathrm{C}$ for $4 \mathrm{~min}$, followed by 35 cycles of $94^{\circ} \mathrm{C}$ for $1 \mathrm{~min}$, $64{ }^{\circ} \mathrm{C}$ (for F435SUB-R) or $66^{\circ} \mathrm{C}$ (for F435INS-R) for $1 \mathrm{~min}$, and $72{ }^{\circ} \mathrm{C}$ for $1 \mathrm{~min}$, then extending at $72{ }^{\circ} \mathrm{C}$ for $10 \mathrm{~min}$ and finally storing at $4{ }^{\circ} \mathrm{C}$. The amplification of PCR products was then confirmed by electrophoresis at $75 \mathrm{~V}$ for $1,5 \mathrm{~h}$ on a $2.0 \%$ agarose gel and visualized with UV light.

\subsection{Statistical and GGE bi-plot analyses}

For each plot, three plants from the center row were used to determine the number of pods, shelling percentage, 100-seed weight and pod yield. 
Combined analysis of variance for two-year data was performed based on location, genotype, and their interactions as sources of variation for morphological and oil traits using SAS 9.3 (SAS Institute, 2011). Least significant differences (LSD) at the 0.05 and 0.01 levels were used to compare the differences among the means.

A GGE bi-plot analysis was performed to display the genotype's main effect $(\mathrm{G})$ and the genotype by environment interaction (GE) for the pod yield data using the "GGEBiplotGUI" package developed by Frutos et al., (2014) in R-project (version 3.3.0) (R Core Team, 2016). The GGE bi-plots were constructed from the first two principal components (PC1 and $\mathrm{PC} 2$ ) produced by the environmentcentered yield data to the singular value composition (Yan, 2002)

\section{RESULTS}

The ANOVA analysis of the genotypes showed a great variation in 100-seed weight and pod yield traits for both locations. The experimental year had no significant effect on the studied traits. The trait of number of pods and shelling percentage showed significant variation among genotypes for the locations of Adana (L1) and Antalya (L2), respectively (Table 1). Overall, the number of pods corresponding to the genotypes were 52.31 for L1 and 56.89 for L2. ACG 107 and ACG 109 had the greatest mean values for number of pods with 77.6 and 72.0 in L1 and L2, respectively. The highest shelling percentage was recorded as $68.5 \%$ from the genotype ACG 116 in L1 and the lowest $55.1 \%$ at the same location for the genotype ACG 154. The trait of 100-seed weight had a greater mean value for L1 than L2; while the control cultivar, NC-7, had the highest mean value for this trait at both locations. Pod yield showed statistically significant differences among genotypes in both experimental areas. The mean value for pod yield was higher in L1 than L2. The highest yields were found in ACG 154 and ACG 107 with the values of 2890.8 and $2110.2 \mathrm{~kg} / \mathrm{ha}$ in locations of L1 and L2, respectively. Location variance was significant for the traits of shelling percentage, 100-seed weight and pod yield (Table 1). The traits of shelling percentage and pod yield also showed significant genotype $\times$ location interaction.

The oil content, oil yield and fatty acid composition for each location are presented in Table 2. Significant differences were observed for palmitic, oleic and linoleic acid among the genotypes in both locations. The trait of oil content showed no significant difference among the genotypes. The mean oil content was higher in L2, although the highest value $(53.6 \%)$ was recorded for the genotype ACG 154 in L1. The oil yield showed significant differences among genotypes and the mean values for this trait were higher in L1 than L2 and ranged from 731.7 to $1198.4 \mathrm{~kg} / \mathrm{ha}$ in $\mathrm{L} 1$, and from 469.8 to $1088.3 \mathrm{~kg} / \mathrm{ha}$ in $\mathrm{L} 2$. The mean oleic acid value was $43.36 \%$ and ranged from 40.1 to $59.9 \%$ in L1.

TABLE 1. Agronomic performance of groundnut genotypes grown in L1 (Adana) and L2 (Antalya)

\begin{tabular}{|c|c|c|c|c|c|c|c|c|c|c|}
\hline \multirow[b]{2}{*}{ Genotypes } & \multirow[b]{2}{*}{ Subspecies } & \multirow{2}{*}{$\begin{array}{l}\text { Botanical } \\
\text { variety }\end{array}$} & \multicolumn{2}{|c|}{ Number of pods } & \multicolumn{2}{|c|}{ Shelling percentage $(\%)$} & \multicolumn{2}{|c|}{ 100-seed weight (g) } & \multicolumn{2}{|c|}{ Pod yield (kg/ha) } \\
\hline & & & Adana & Antalya & Adana & Antalya & Adana & Antalya & Adana & Antalya \\
\hline ACG 14 & fastigiata & vulgaris & 69.5 & 71.2 & 61.5 & 66.2 & 40.7 & 35.3 & 2280.7 & 1690.0 \\
\hline ACG 107 & fastigiata & vulgaris & 77.6 & 71.1 & 65.4 & 67.9 & 36.2 & 36.5 & 2020.8 & 2110.2 \\
\hline ACG 109 & fastigiata & fastigiata & 56.2 & 72.0 & 61.1 & 59.6 & 37.0 & 36.7 & 1480.5 & 2050.1 \\
\hline ACG 116 & fastigiata & vulgaris & 48.2 & 49.1 & 68.5 & 62.3 & 41.4 & 40.4 & 2230.5 & 1900.3 \\
\hline ACG 154 & hypogaea & hypogaea & 47.5 & 35.7 & 55.1 & 56.8 & 63.2 & 58.2 & 2890.8 & 930.5 \\
\hline ACG 155 & fastigiata & vulgaris & 56.2 & 53.8 & 66.1 & 71.2 & 39.2 & 30.4 & 1860.8 & 1220.6 \\
\hline ACG 156 & fastigiata & vulgaris & 58.1 & 61.5 & 60.9 & 69.8 & 37.9 & 29.4 & 1920.7 & 1360.5 \\
\hline ACG 158 & fastigiata & vulgaris & 33.9 & 47.3 & 62.7 & 66.3 & 45.0 & 37.9 & 1390.1 & 1570.7 \\
\hline ACG 159 & fastigiata & vulgaris & 44.7 & 56.6 & 63.3 & 65.3 & 35.7 & 26.4 & 1840.8 & 1370.2 \\
\hline NC-7 & hypogaea & hypogaea & 39.9 & 59.5 & 62.8 & 69.0 & 97.0 & 75.5 & 2270.8 & 1960.2 \\
\hline Florispan & fastigiata & fastigiata & 43.9 & 48.2 & 63.8 & 66.5 & 51.2 & 38.9 & 1630.8 & 1450.2 \\
\hline Means & & & 52.31 & 56.89 & 62.80 & 65.54 & 47.64 & 40.51 & 1980.93 & 1600.41 \\
\hline LSD & & & $15.32 * *$ & $\mathrm{~ns}$ & ns & $3.66 * *$ & $1.95 * *$ & $3.55^{* *}$ & 76.97* & $680.74 *$ \\
\hline \multicolumn{3}{|l|}{ Location } & \multicolumn{2}{|c|}{ ns } & \multicolumn{2}{|c|}{$* *$} & \multicolumn{2}{|c|}{$* *$} & \multicolumn{2}{|c|}{ 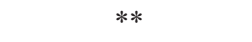 } \\
\hline \multicolumn{3}{|c|}{ Location $\times$ Genotype } & \multicolumn{2}{|c|}{ ns } & \multicolumn{2}{|c|}{$\mathrm{ns}$} & \multicolumn{2}{|c|}{ * } & \multicolumn{2}{|c|}{ 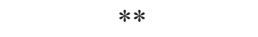 } \\
\hline
\end{tabular}

"Means are the average of 3 replicates

*, **: Statistically significant at $\mathrm{P}=0.05$ and $\mathrm{P}=0.01$ significance level, respectively. ns is non-significant LSD is least significant differences 
Influences of genotype and location interactions on oil, fatty acids and agronomical properties of groundnuts $\bullet 5$

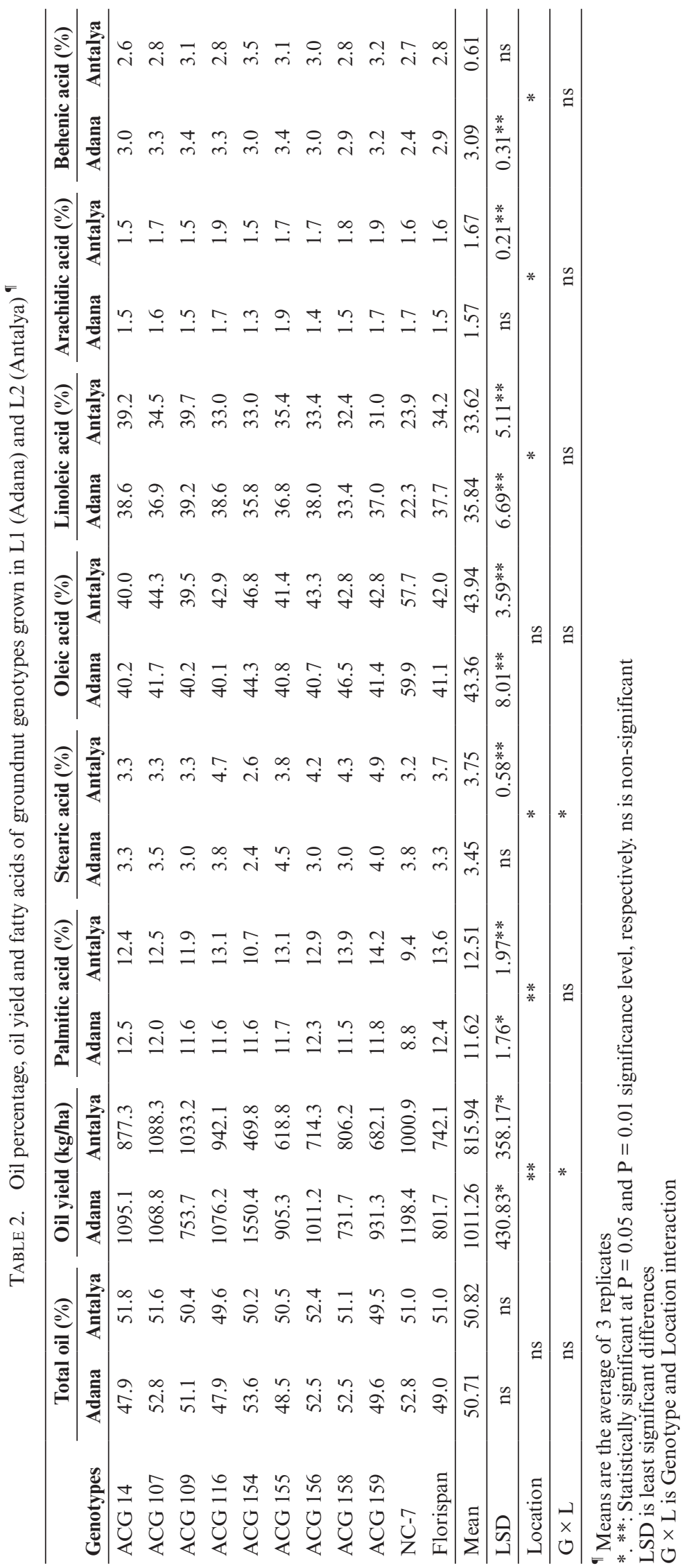

Grasas Aceites 69 (4), October-December 2018, e276. ISSN-L: 0017-3495 https://doi.org/10.3989/gya.0109181 
The minimum oleic acid value was $39.5 \%$ for the genotype ACG 109 in L2. The control, NC-7 had higher oleic acid values than the genotypes studied for both experimental areas. Linoleic acid varied from 22.3 (NC-7) to 39.21\% (ACG 109) with a mean value of $35.84 \%$ in L1. These same genotypes also had the minimum and maximum values in the other location (Table 2). Palmitic acid is the major saturated fatty acid in groundnut oil and its content ranged from 11.5 to $12.5 \%$ and 10.7 to $14.2 \%$ in L1 and L2, respectively. The effect of location was significant for all oil traits except for total oil percent and oleic acid (Table 2). The genotype $\times$ location interaction was significant only for oil yield and stearic acid, and was non-significant for other oil traits.

Functional SNP mutations of the ahFAD2A $(448 \mathrm{G} \rightarrow \mathrm{A})$ and $a h F A D 2 B$ (442insA) genes were detected by allele-specific PCR markers. Three genotypes, ACG 14, ACG 154 and ACG 156, had the mutation in the ahFAD2A gene (Figure 2). There was no functional mutation detected on the
B genome in the groundnut genotypes of this study. The high-oleic acid control genotype also carried the mutation. In this analysis, the high oleic control line showed a PCR product of 195-bp including an A:T insertion. However, the other control, NC-7, showed no functional SNP mutation.

The partitioning of GGE through a GGE bi-plot analysis showed that PCA 1 and PCA 2 accounted for $65.13 \%$ and $34.87 \%$ for pod yield as shown in Figure 3. The GGE bi-plot indicated that the genotypes ACG 107 and ACG 109 were highly related with L2, while ACG 154 was for L1. ACG 14 and ACG 116 indicated high stability in both locations (Figure 4).

\section{DISCUSSION}

The knowledge about genotype $\times$ location interaction is necessary for plant breeding programs to select desirable genotypes which are adapted or stable to target regions. This study was undertaken to determine elite genotypes with respect to agronomic
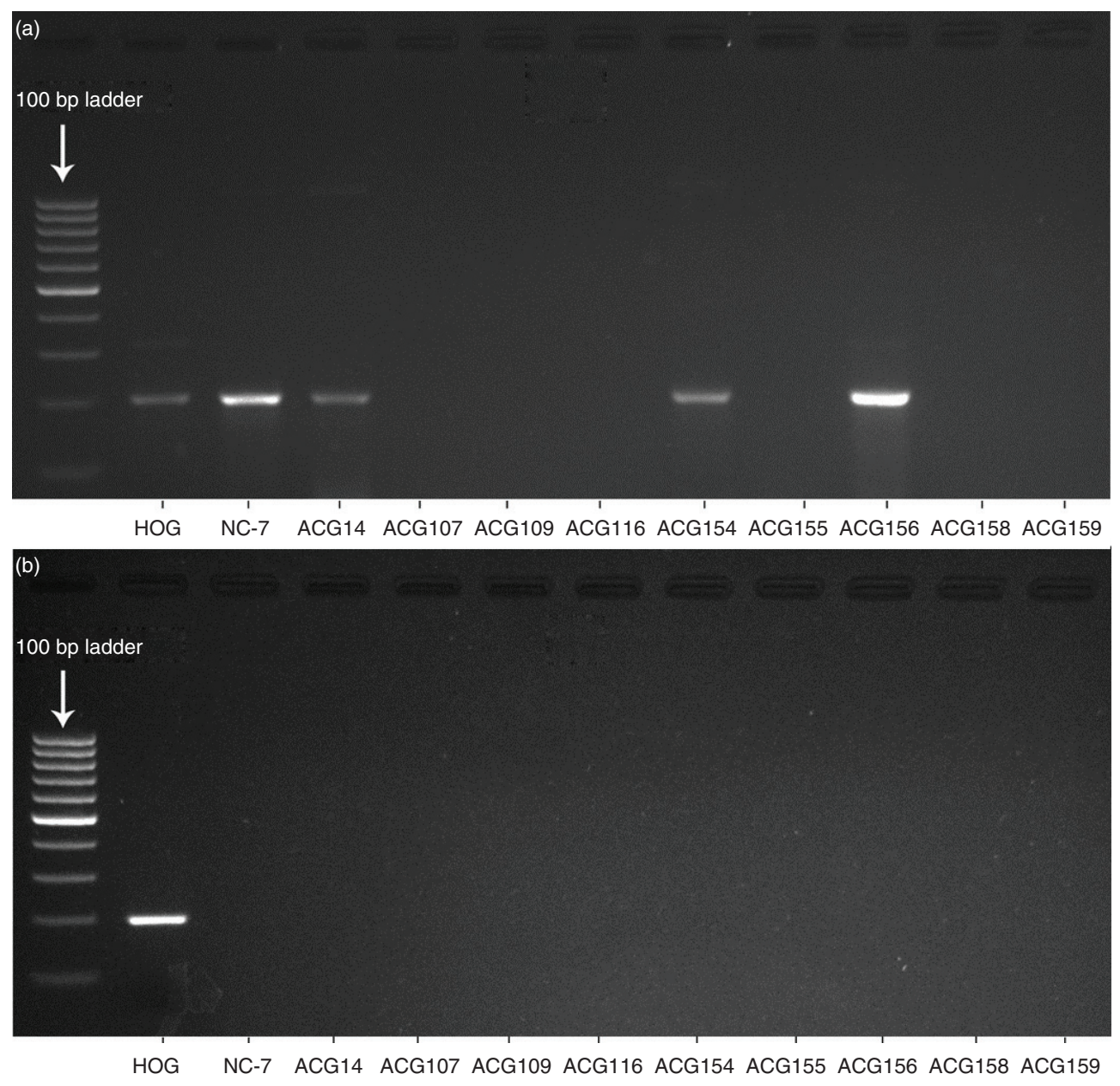

FIGURE 2. The figures (a) and (b) showed genotyping of genotypes with allele-specific PCR markers for selection of mutant alleles for A-genome and B-genome mutation, respectively. The 'HOG' is high oleic line and 'NC-7' is normal oleic cultivar. 
and oil traits for two different Mediterranean environments. The trait of number of pods is an important yield criterion to obtain a higher yield from groundnuts (Luz et al., 2011). In this study, it showed a wide variation among genotypes because of the different responses of each genotype to the growing locations. Upadhyaya et al., (2005) obtained differences in number of pods among the genotypes of the ICRISAT groundnut core collection grown in Asia. This trait indicated no significant interaction with genotype $\times$ location, which is critical to develop highly stable cultivars in the Mediterranean areas.

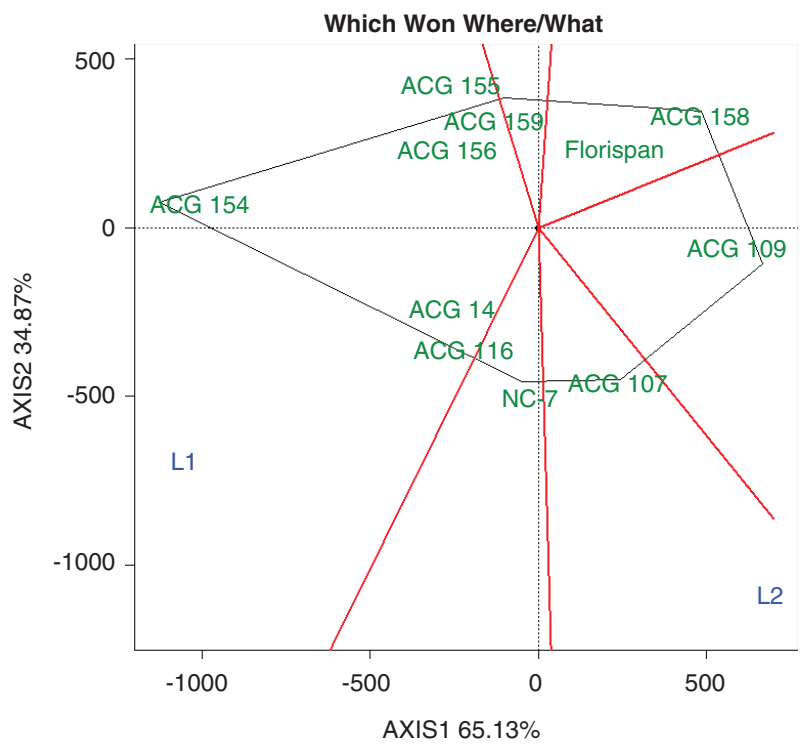

FIGURE 3. GGE Bi-plot analysis (which shows where and which is best for what) for pod yield trait of groundnut genotypes in two different locations. L1 is Adana location and L2 is Antalya location of Turkey.

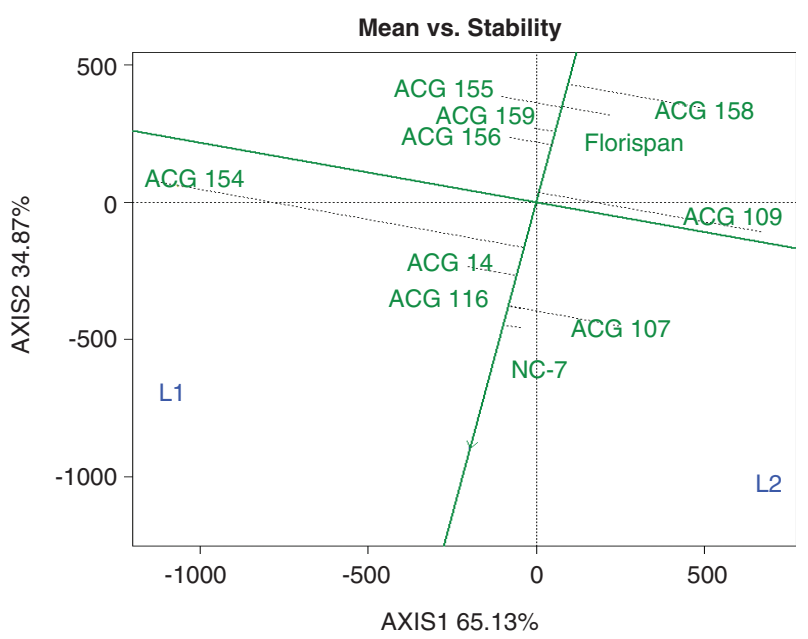

FIGURE 4. GGE bi-plot for performance and stability of groundnut genotypes for pod yield trait. L1 is Adana location and L2 is Antalya location of Turkey.
However, Swamy et al., (2003) reported that number of pods showed significant variation due to the genotype $\times$ location interaction. This result may be explained by different environmental effects on the locations or genotypes. The highest number of pods was observed for ACG 14 which also had very high pod yield in L1 and this type of positive correlation was also obtained by Jiang et al., (2014) for the Chinese groundnut collection.

Shelling percentage is strongly influenced by genotype (Hartmond et al., 1996), locational differences (Padi, 2008) and positively related to pod yield in groundnuts (Anothai et al., 2008). In the present study, the genotypes showed significant differences for shelling percentage in L2. The genotypes which belong to var. vulgaris had higher shelling percentage values than var. hypogaea and var. fastigiata types in both locations (Table 1). This result agrees with the previous report on groundnuts by Upadhyaya (2003), who evaluated 1704 genotypes. Location had a significant effect on the genotypes for shelling percentage in this study. Interactions were also found by Padi (2008). The location effect should therefore be taken into consideration in groundnut breeding programs in order to select genotypes for the shelling percentage trait. The most desirable genotypes possessing higher shelling percentages were ACG 116 from L1 and ACG 155 from L2 with the values of 68.5 and $71.2 \%$, respectively. These results were greater compared to the US groundnut core collection (Holbrook et al., 1993) and Asian groundnut core collection (Swamy et al. 2003). These genotypes were also superior to the controls, NC-7 and Florispan.

The variance components for genotype, location and their interaction were significant for 100 -seed weight, indicating that the genotypes were only different from each other for this trait and also interacted with the location. Similar significant differences were reported by Swamy et al., (2003) and Upadhyaya et al., (2005). ACG 154 had greater 100-seed weight compared to other genotypes at both locations, with the exception of the control, NC-7. There are four commercial types of groundnuts: Virginia, Runner, Spanish, and Valencia. Virginia and Runner belong to the subsp. hypogaea, while Spanish and Valencia belong to the subsp. fastigiata. Generally, snack industries prefer Virginia and Runner commercial types because of their larger seeds. Smaller seeds are mostly used for the confectionary and oil industries. Suassuna et al., (2015) categorized the genotypes as Runner commercial and Jumbo, which have seed weights of $50-70$ g per 100 and higher than $70 \mathrm{~g}$, respectively. The genotype ACG 154 from both locations had 50-70 g seed weight and they should be good sources for the Runner commercial type. This genotype also belongs to the subsp. hypogaea var. hypogaea and similarly 
the subsp. hypogaea had higher mean values in the Asian core collection compared to the subsp. fastigiata for this trait (Swamy et al., 2003).

The purpose of establishing advanced groundnut germplasm is to facilitate efficient and economical utilization of genetic resources to identify genotypes with desirable traits. The genotypes used in the present investigation were selected from 256 genotypes which were evaluated in three consecutive years to identify the most suitable genotypes for Mediterranean areas (Yol et al., 2018). After two years of field evaluation, the genotypes, ACG 116 and ACG 154 in L1 and ACG 107 in L2 showed significantly greater mean values for pod yield compared to the controls and the rest of the genotypes. Location and location $\times$ genotype interaction also showed significant effects on pod yield. This could be an advantage in breeding programs because a significant genotype $\times$ location interaction for pod yield increases selection efficiency for a specific location. The GGE bi-plot revealed the most suitable genotypes with respect to pod yield, which were ACG 107 and ACG 109 in L2; whereas the genotype ACG 154 was suitable for the environment L1. However, they were unstable over the locations based on the GGE bi-plot analyses (Figure 4). ACG 116 and ACG 107 had high pod yield in all locations (Table 1) and they were relatively stable in both environments (Figure 4), making them the most suitable for production across locations with regard to yield stability. These high-yielding genotypes from the subsp. fastigiata var. vulgaris should provide better opportunities to develop elite cultivars which are suitable for Mediterranean regions.

The effect of genotype was highly significant for palmitic, oleic and linoleic acid in the present study and similar results were reported by Dwivedi et al., (1993). The genotype $\times$ location interaction was non-significant for the studied oil traits except for stearic acid. The non-significant interaction indicated that oil traits showed stability over the different Mediterranean locations. The highest oil content was observed for ACG 154 in L1 and ACG 156 in L2, which belong to var. hypogaea and var. vulgaris, respectively. Similarly, higher oil content values were obtained for different botanical varieties among 5700 groundnut genotypes tested by Liao (2003). The genotypes ACG 116 and ACG 159 had oil contents lower than $50 \%$ in both locations; although they could be preferred by the food industry for their low calorific values (Janila et al., 2016). The groundnut is an industrial crop and yield must be combined with quality traits for optimal commercial products. Therefore, oil yield is an important selection criterion for developing cultivars with high oil and seed yield (Baydar, 2005). The genotypes ACG 116 and ACG 107 had higher oil yield and were relatively stable across locations and thus should be evaluated as candidate cultivars in the studied climatic areas.
The quality of groundnut oil is determined by oleic and linoleic acid contents, which comprise over $80 \%$ of the groundnut oil content (Liao and Holbrook, 2007). The highest oleic acid content was observed in the control NC-7 with mean values of $59.9 \%$ and $57.7 \%$ in $\mathrm{L} 1$ and $\mathrm{L} 2$, respectively. The 1-bp substitution $(\mathrm{G}: \mathrm{C} \rightarrow \mathrm{A}: \mathrm{T})$ at position 448 of $a h F A D 2 A$ and 1-bp insertion (A:T) at position 442 of $a h F A D 2 B$ frameshift mutations resulted in reduced amounts of linoleic acid and significantly increased amounts of oleic acid in the groundnuts (Jung et al., 2000, López et al., 2000). The breeding lines, ACG 14, ACG 154 and ACG 156 only carry ahFAD2A mutations and have normal oleic contents (Table 2). Because each gene mutation causes a limited amount of oleic acid increase, another homologous gene compensates for the conversion of oleic acid to linoleic acid (Wang et al., 2011). Many commercial cultivars such as SunOleic 95R (Gorbet and Knauft, 1997), and OLé (Chamberlin et al., 2015) have been released with a high oleic content of about $80 \%$ and carry functional $a h F A D 2 A$ and $a h F A D 2 B$ mutations. These cultivars are largely used in the US food industry and therefore there is a need for high oleic cultivars which are suitable for the studied locations. Palmitic acid is major saturated fatty acid in groundnut oil and showed lower values in genotypes which have high oleic acid contents (Table 2). The negative correlation was also mentioned by Wang et al., (2010) indicating that when the amount of oleic acid is increased in seeds, the amount of palmitic acid is decreased.

\section{ACKNOWLEDGMENTS}

This study was supported by the Ministry of Science, Industry and Technology of Turkey with the grant number of SANTEZ- 01527-STZ-2012-2. We appreciate the Scientific Research Projects Coordination Unit of Akdeniz University for continuous support and are grateful to ICRISAT Gene bank, Hyderabad, India for supplying genetic material.

\section{REFERENCES}

Ahmed EM, Young CT. 1982. Composition, quality, and flavor of peanuts, in Pattee HE, Young CT (Eds.). Peanut science and technology. American Peanut Research and Education Society, Yoakum, pp. 655-688.

Anothai J, Patanothai A, Pannangpetch K, Jogloy S, Hoogenboom G, Boote KJ. 2008. A sequential approach for determining the cultivar coefficients of peanut lines using end-of-season data of crop performance trials. Field Crops Res. 108, 169-178. https://doi.org/10.1016/j.fcr.2008. 04.012

Badigannavar AM, Kale DM, Murty GSS. 2002. Genetic base and diversity in peanut genotypes. Plant Breeding 121, 348-353. https://doi.org/10.1046/j.1439-0523.2002.00710.x

Baydar H. 2005. Breeding for the improvement of the ideal plant type of sesame. Plant Breeding 124, 263-267. https://doi. org/10.1111/j.1439-0523.2005.01080.x 
Caliskan S, Caliskan ME, Arslan M, Arioglu H. 2008. Effects of sowing date and growth duration on growth and yield of groundnut in a Mediterranean-type environment in Turkey. Field Crops Res. 105, 131-140. https://doi.org/10.1016/j. fcr.2007.08.007

Chamberlin KD, Bennett RS, Damicone JP, Godsey CB, Melouk HA, Keim K. 2015. Registration of 'OLe' peanut. J. Plant Regist. 9, 154-158. https://doi.org/10.3198/ jpr2014.10.0072crc

Chen W, Jiao Y, Cheng L, Huang L, Liao B, Tang M, Ren X, Zhou X, Chen Y, Jiang H. 2016. Quantitative trait locus analysis for pod- and kernel-related traits in the cultivated peanut (Arachis hypogaea L.). BMC Genetics 17, 25. https://doi.org/10.1186/s12863-016-0337-x

Chen Z, Wang ML, Barkley NA, Pittman RN. 2010. A simple allele-specific PCR assay for detecting FAD2 alleles in both $\mathrm{A}$ and $\mathrm{B}$ genomes of the cultivated peanut for high-oleate trait selection. Plant Mol. Biol. Rep. 28, 542-548. https:// doi.org/10.1007/s11105-010-0181-5

Chu Y, Holbrook CC, Ozias-Akins P. 2009. Two alleles of ahFAD2B control the high oleic acid trait in cultivated peanut. Crop Sci. 49, 2029-2036. https://doi.org/10.2135/ cropsci2009.01.0021

Chu Y, Ramos ML, Holbrook CC, Ozias-Akins P. 2007. Frequency of a loss-of-function mutation in oleoyl-PC desaturase (ahFAD2A) in the mini-core of the U.S. peanut germplasm collection. Crop Sci. 47, 2372-2378. https://doi. org/10.2135/cropsci2007.02.0117

Cook BG, Crosthwaite IC. 1994. Utilization of Arachis species as forage, in Smartt J (Ed.). The groundnut crop: A scientific basis for improvement. Chapman and Hall, London, UK, pp. $624-663$

Doyle JJ. Doyle JL. 1990. Isolation of plant DNA from fresh tissue. Focus 12, 13-15.

Dwivedi SL, Nigam SN, Jambunathan R, Sahrawat KL, Nagabhushanam GVS, Raghunath, K. 1993. Effect of genotypes and environments on oil content and oil quality parameters and their correlation in peanut (Arachis hypogaea L.). Peanut Sci. 20, 84-89.

FAO. 2014. FAOSTAT. [2017-06-01]. http://faostat.fao.org/ site/567/default.aspx

Frutos E, Galindo MP, Leiva V. 2014. An interactive biplot implementation in $\mathrm{R}$ for modeling genotype-by-environment interaction. Stoch. Environ. Res. Risk. Assess. 28, 1629-1641. https://doi.org/10.1007/s00477-013-0821-z

Garcés R, Mancha M. 1993. One-step lipid extraction and fatty acid methyl esters preparation from fresh plant tissues. Anal. Biochem. 211, 139-143.

Gorbet DW, Knauft DA. 1997. Registration of 'SunOleic 95R' peanut. Crop Sci. 37, 1392

Halward TM, Wynne JC. 1991. Generation means analysis for productivity in two diverse peanut crosses. Theor. Appl. Genet. 82, 784-792. https://doi.org/10.1007/BF00227326

Hammons RO. 1994. The origin and history of the groundnut, in Smartt J (Ed.). The groundnut crop: A scientific basis for improvement. Chapman and Hall, London, UK, pp. 2442.

Hartmond U, Williams JH, Lenz F. 1996. Sources of variation in shelling percentage in peanut germplasm and crop improvement for calcium deficiency-prone soils. Peanut Sci. 23, 76-81.

Holbrook CC, Anderson WF, Pittman RN. 1993. Selection of a core collection from the U.S. germplasm collection of peanut. Crop Sci. 33, 859-861. https://doi.org/10.2135/cropsci 1993.0011183X003300040044x

Janila P, Pandey MK, Shasidhar Y, Variath MT, Sriswathi M, Khera P, Manohar SS, Nagesh, P, Vishwakarma MK, Mishra GP, Radhakrishnan T, Manivannan N, Dobariya KL, Vasanthi RP, Varshney RK. 2016. Molecular breeding for introgression of fatty acid desaturase mutant alleles $(a h F A D 2 A$ and $a h F A D 2 B)$ enhances oil quality in high and low oil containing peanut genotypes. Plant Sci. 242, 203-213. https://doi.org/10.1016/j.plantsci.2015.08.013

Jiang H, Huang L, Ren X, Chen Y, Zhou X, Xia Y, Huang J, Lei Y, Yan L, Wan L, Liao B. 2014. Diversity characterization and association analysis of agronomic traits in a Chinese peanut (Arachis hypogaea L.) mini-core collection.
J. Integr. Plant Biol. 56, 159-169. https://doi.org/10.1111/ jipb.12132

Jung S, Swift D, Sengoku E, Patel M, Teule F, Powell G, Moore $\mathrm{K}$, Abbott A. 2000. The high oleate trait in the cultivated peanut [Arachis hypogaea L.]. I. Isolation and characterization of two genes encoding microsomal oleoyl-PC desaturases. Mol. Genet. Genomics 263, 796-805. https://doi. org/10.1007/s004380000244

Liao BS. 2003. The groundnut. Wuhan: Hubei Press for Science and Technology.

Liao B, Holbrook C. 2007. Groundnut, in Singh RJ (Ed.). Genetics resources, chromosome engineering and crop Improvement, Oilseed crops. CRC Press, Boca Raton, FL, pp. 51-87.

López Y, Nadaf HL, Smith OD, Connell JP, Reddy AS, Fritz AK. 2000. Isolation and characterization of the Delta (12)-fatty acid desaturase in peanut (Arachis hypogaea L.) and search for polymorphisms for the high oleate trait in Spanish market-type lines. Theor. Appl. Genet. 101, 1131-1138. https:// doi.org/10.1007/s001220051589

Luz LN, Santos RC, Filho PAM. 2011. Correlations and path analysis of peanut traits associated with the peg. Crop Breed. Appl. Biotechnol. 11, 88-93. https://doi.org/10.1590/ S1984-70332011000100013

Padi KF. 2008. Genotype 3 environment interaction for yield and reaction to leaf spot infections in groundnut in semiarid West Africa. Euphytica 164, 143-161.

Phan-Thien K, Wright G, Tillman B, Lee A. 2014. Peanut antioxidants: Part 1. Genotypic variation and genotype by environment interaction in antioxidant capacity of raw kernels. LWT-Food Sci. Technol. 57, 306-311. https://doi. org/10.1016/j.lwt.2013.12.021

R Development Core Team. 2016. R: A language and environment for statistical computing, available at www.r-project.org

SAS Institute. 2011. SAS/STAT software 9.3, SAS Institute, Cary, NC

Suassuna TMF, Suassuna ND, Moretzsohn MC, Bertioli SCML, Bertioli DJ, Medeiros EP. 2015. Yield, market quality, and leaf spots partial resistance of interspecific peanut progenies. Crop Breed. Appl. Biotechnol. 15, 175-180. https://doi. org/10.1590/1984-70332015v15n3n30

Swamy BPM, Upadhyaya HD, Goudar PVK, Kullaiswamy BY, Singh S. 2003. Phenotypic variation for agronomic characteristics in a groundnut core collection for Asia. Field Crops Res. 84, 359-371. https://doi.org/10.1016/ S0378-4290(03)00102-3

Terés S, Barceloi-Coblijn G, Menet M, Ailvarez R, Bressani R, Halver JE and Escribaì PV. 2008. Oleic acid content is responsible for the reduction in blood pressure induced by olive oil. Proc. Natl. Acad. Sci. USA 105, 13811-13816. https://doi.org/10.1073/pnas.0807500105

Upadhyaya HD, Ortiz R, Bramel PJ, Singh S. 2003. Development of a groundnut core collection using taxonomical, geographical and morphological descriptors. Genet. Resour. Crop Evol. 50, 139-148. https://doi.org/10.1023/A:1022945715628

Upadhyaya HD, Swamy BPM, Goudar PVK, Kullaiswamy BY, Singh S. 2005. Identification of diverse groundnut germplasm through multienvironment evaluation of a core collection for Asia. Field Crops Res. 93, 293-299. https://doi. org/10.1016/j.fcr.2004.10.007

Wang ML, Barkley NA, Chen Z, Pittman RN. 2011. FAD2 gene mutations significantly alter fatty acid profiles in cultivated peanuts (Arachis hypogaea). Biochem. Genet. 49, 748-759. https://doi.org/10.1007/s10528-011-9447-3

Wang ML, Chen CY, Davis J, Guo B, Stalker HT, Pittman RN. 2010. Assessment of oil content and fatty acid composition variability in different peanut subspecies and botanical varieties. Plant Genet. Resour. 8, 71-73. https://doi.org/10.1017/ S1479262109990177

Yan W. 2002. Singular-value partitioning in biplot analysis of multi environment trial data. Agron. J. 94, 990-996. https:// doi.org/10.2134/agronj2002.0990

Yol E, Upadhyaya HD, Furat S, Uzun B. 2018. Characterization of groundnut (Arachis hypogaea L.) collection using quantitative and qualitative traits in the Mediterranean basin. J. Integr. Agric. 17, 63-75. https://doi.org/10.1016/ S2095-3119(17)61675-7 
Yol E, Upadhyaya HD, Uzun B. 2015. Molecular diagnosis to identify new sources of resistance to sclerotinia blight in groundnut (Arachis hypogaea L.). Euphytica 203, 367-374. https://doi.org/10.1007/s10681-014-1282-2

Yol E, Upadhyaya HD, Uzun B. 2016. Identification of rust resistance in groundnut using a validated SSR marker.
Euphytica 210, 405-411. https://doi.org/10.1007/s10681016-1705-3

Yol E, Ustun R, Golukcu M, Uzun B. 2017. Oil content, oil yield and fatty acid profile of groundnut germplasm in Mediterranean climates. J. Am. Oil Chem. Soc. 94, 787-804. https://doi.org/10.1007/s11746-017-2981-3 